\title{
AS LEGISLAÇÕES URBANÍSTICAS E O DESENHO DA CIDADE POPULAR: $O$ caso do Recife/Brasil
}

\author{
Andresa Santana \\ Historiadora. \\ Pós Graduação em Desenvolvimento Urbano- Universidade Federal de Pernambuco. \\ santana.andresab@gmail.com \\ Amélia Reynaldo \\ Arquiteta. \\ Doutora pela Escola Técnica Superior de Arquitetura de Barcelona (1998). \\ Coordenadora da pesquisa em curso. \\ ameliareynaldo@yahoo.com.br
}

\section{RESUMO}

No âmbito do estudo sobre o processo da origem da urbanização do Recife, especialmente através do parcelamento do solo, entre as décadas de 1920 e 1980, verificou-se a forte presença dos loteamentos denominados como populares, voltados para população de baixa renda, onde a grande maioria é aprovada entre as décadas de 1940 e 1950, sendo desenhada pela legislação urbanística do Regulamento de Construções de 1936, que fornece os parâmetros de desenho e ocupação do solo urbano. Ao passo que a cidade formal era desenhada pelas legislações urbanísticas e pela política habitacional, a cidade informal era igualmente desenhada pelas exclusões ocasionadas por essas políticas. A ausência de estudos sobre o processo de urbanização da cidade do Recife através dos loteamentos populares, compreendendo quais as bases legais foram utilizadas para auxiliar no problema da moradia da população de baixa renda, torna a presente pesquisa crucial na compreensão da cidade popular.

Palavras chaves: urbanização, loteamento popular, parcelamento do solo.

\begin{abstract}
In the scope of the study on the process of origin of urbanization in Recife, especially through land subdivision, between the 1920s and 1980s, there was a strong presence of the so-called popular land lots, aimed at the low income population, where the great majority was approved between the 1940s and 1950s, and was drawn by the urban legislation of the Building Regulations of 1936, which provides the parameters of urban land design and occupation. While the formal city was drawn by urban planning legislation and housing policy, the informal city was also designed by the exclusions occasioned by these policies. The lack of studies on the process of urbanization of the city of Recife through the popular settlements, understanding the legal bases to solve the housing issues for the low-income population, makes the present research crucial in understanding the popular city.
\end{abstract}

Keywords: Urbanization, popular subdivision, land subdivision. 


\section{INTRODUÇÃO}

Até princípios do século $X X$ a cidade do Recife é marcada por um crescimento urbano que seguia os antigos caminhos dos engenhos, caracterizado pela ausência de uma política habitacional e, concomitantemente, pela forte presença dos mocambos, tipo de habitação construído com materiais locais e estabelecido, geralmente, em alagados e mangues. Com o crescimento populacional e das doutrinas do urbanismo sanitarista, a cidade inicia seu desenho de crescimento urbano através do parcelamento do solo, legitimadas pelas legislações urbanísticas.

O início do século XX é marcado pela reforma do porto que, de acordo com Reynaldo (2013) impulsiona a criação de um novo solo urbano. Até este período os sobrados eram implantados em estreitos lotes, o que será modificado em meados do século XIX, após 1840, com a expansão e modernização da cidade. A obrigação de amplos recuos ou afastamentos auxilia no delineamento do novo traçado urbano. Ainda de acordo com Reynaldo (Op. Cit., p. 08):

O estudo da expansão urbana do Recife no século XX se inicia com a análise do regulamento de construção de 1919 (lei n. 1.051 de 11/09/1919), primeiro documento que normatiza a ocupação da cidade do Recife por meio da delimitação da zona central e da definição da inadequação do sobrado como habitação nas demais zonas, incrementando a construção isolada no terreno como modelo edificatório das novas áreas urbanas.

A partir dos estudos realizados sobre o processo de urbanização da cidade do Recife, no século $X X$, resultado da análise das fichas de cadastros urbanísticos cedidas pela Empresa de Urbanização do Recife (URB), com um total 1.798 loteamentos, que caracterizam o processo de urbanização da cidade entre os anos de 1920 e 1980, verifica-se uma maior quantidade de loteamentos aprovados entre as décadas de 1940 e 1950. Através destas fichas e das plantas de loteamentos identificadas até o momento, num total de 850, cerca de 300 são caracterizados como loteamentos populares, ou seja, pouco mais de $30 \%$ dos loteamentos identificados. Salienta-se que, o termo loteamentos populares utilizado na presente pesquisa, diz respeito aos loteamentos que não contém os tamanhos mínimos exigidos pelas legislações urbanísticas, assim como aqueles que são denominados nas plantas de loteamentos como sendo populares.

Até princípios do século $X X$, não havia uma política habitacional no Recife, o que levou a população de baixa renda a procurar os mocambos como moradia. As legislações urbanísticas atreladas às políticas habitacionais adotadas pelo Estado, nesse período, regulamentaram a construção de uma cidade popular que não supriu o direito à moradia da população de baixa renda, contribuindo para construção de uma cidade fragmentada. Observa-se, assim, uma cidade formal, projetada pelo Estado, estudada aqui através do parcelamento do solo; e uma cidade informal, que cresceu especialmente pela ineficaz política de planejamento adotada na cidade. Ambas são caracterizadas pela população de baixa renda.

A análise dos respectivos loteamentos populares à luz das legislações urbanísticas, especialmente pelo Regulamento de Construções de 1936 e o Código de Obras de 1961, que rege a quase totalidade desses loteamentos encontrados até o momento, permite verificar, (i) quais as áreas da cidade eram destinadas à população de baixa renda, (ii) quais as diferenças entre os loteamentos populares e os não populares, (iii) quais os benefícios que as legislações garantiam a essa população, levando-se em consideração a infraestrutura, equipamentos públicos e áreas livres; e, por fim, (iv) quais as características das habitações destinadas a esse público.

Assim, o presente artigo tem como objetivo identificar como as legislações urbanísticas auxiliaram legalmente nas soluções adotadas tanto pelo Estado, quanto por particulares, para suprir as questões relacionadas ao direito à moradia pela população de baixa renda, no tocante as diretrizes de parcelamento do solo e as construções habitacionais, levando em consideração os parâmetros de desenho, ocupação dos terrenos, áreas e equipamentos públicos e, principalmente, as infraestruturas exigidas para essas áreas entre as décadas de 1920 e 1980.

Para o desenvolvimento da presente pesquisa, serão adotados os seguintes procedimentos metodológicos:

(i) Identificação das diretrizes de parcelamento do solo e construções, elencados nas legislações urbanísticas, responsáveis pela aprovação dos loteamentos populares aprovados entre os anos 1920 e 1980;

(ii) Análise das plantas dos loteamentos populares aprovados pela Prefeitura da Cidade do Recife, identificando às exigências aprovadas pelas legislações no tocante a esses loteamentos específicos; 
(iii) Estudo das políticas habitacionais adotadas pelo Estado de Pernambuco no referido período, buscando compreender o contexto da aprovação de tais loteamentos.

\section{O PROCESSO DE URBANIZAÇÃO DO RECIFE ATRAVÉS DO PARCELAMENTO DO SOLO}

\subsection{A expansão da cidade até o início do século XX}

O processo de urbanização da cidade do Recife inicia-se efetivamente em meados do século XVII, moldado por um contexto cultural singular, devido à ocupação holandesa. Após a chegada flamenga, o Recife passa a se desenvolver como cidade, além do porto. Atraídos pela riqueza e localização estratégica de Pernambuco, ao invés de se estabelecerem no sítio de Olinda, os novos ocupantes preferiram as terras baixas do Recife, pois a primeira não favorecia aos seus interesses militares e comerciais.

A trama urbana do centro da cidade vai sendo delineada e novos bairros vão surgindo com o decorrer dos anos. A população cresce e com ela aumenta a quantidade de aterros e o processo de adentrar pelo território. A paisagem da cidade é marcada pelas igrejas, que serviram como ordenadores do espaço urbano, bem como pelas ruas, becos e sobrados.

O século XIX marca um grande crescimento populacional devido às consequências da Revolução Industrial, que previa a produção em massa. A economia pernambucana sofre significativas modificações, especialmente o grande centro de comercialização que era a cidade do Recife. Inicia-se a inserção de indústrias, especialmente na fabricação do açúcar. Além das indústrias no setor metalúrgico, diretamente ligadas à fabricação do açúcar, destacam-se as indústrias ligadas à fiação e tecelagem. Nesse momento surgem as fábricas da Torre, de Camaragibe, do Paulista, de Goiana e a Usina Beltrão, posteriormente denominada como Fábrica Tacaruna (gráfico 01). Com o crescimento na produção dos tecidos, há uma ampliação das instalações fabris e, consequentemente no número de trabalhadores morando próximo às fábricas.

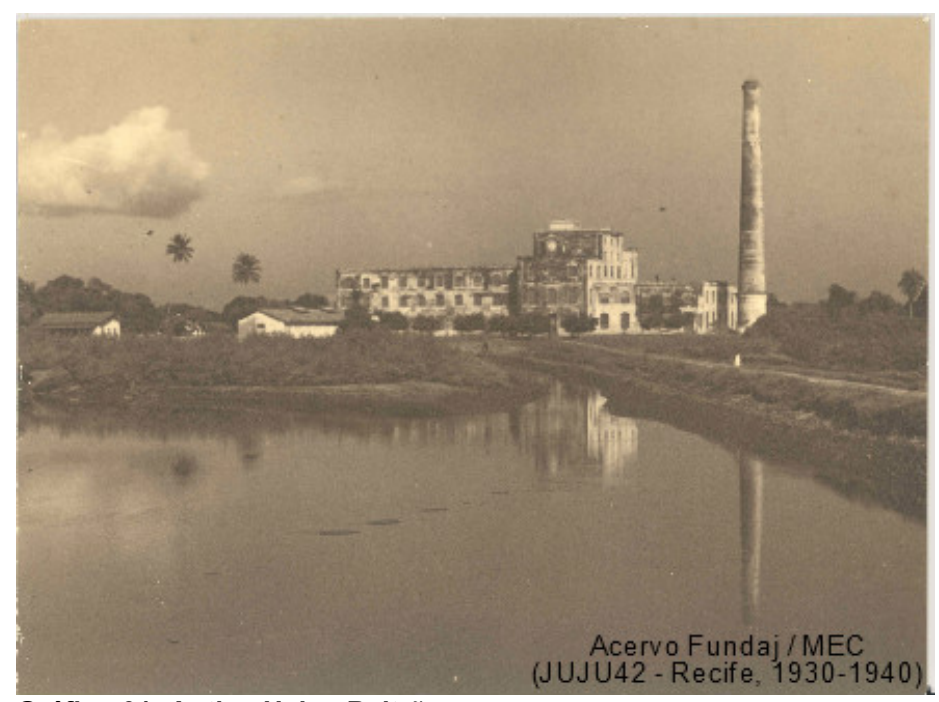

Gráfico 01- Antiga Usina Beltrão.

(Acervo Fundaj.)

Todos os testemunhos são concordes em confirmar a acelerada expansão urbana do Recife no século XIX. É no decorrer deste século que o crescimento da cidade se começa a fazer em ritmo acelerado e se desenvolvem os seus foros de metrópole. [...] $O$ engrossamento do fluxo comercial por Recife teve, portanto, significativas consequências para a cidade, que se moderniza, e adapta à sua função comercial sobremodo ampliada. (SINGER, 1977, p.290-291)

O desenvolvimento industrial, além da diversificação do sistema produtivo, acarreta num crescimento e alta concentração populacional no Recife, trazendo impactos na sua expansão urbana. De acordo com Lubambo (1991) a cidade, que já apresentava considerável mercado de consumo, tem sua população triplicada entre meados do século XIX e a primeira década do século XX. 


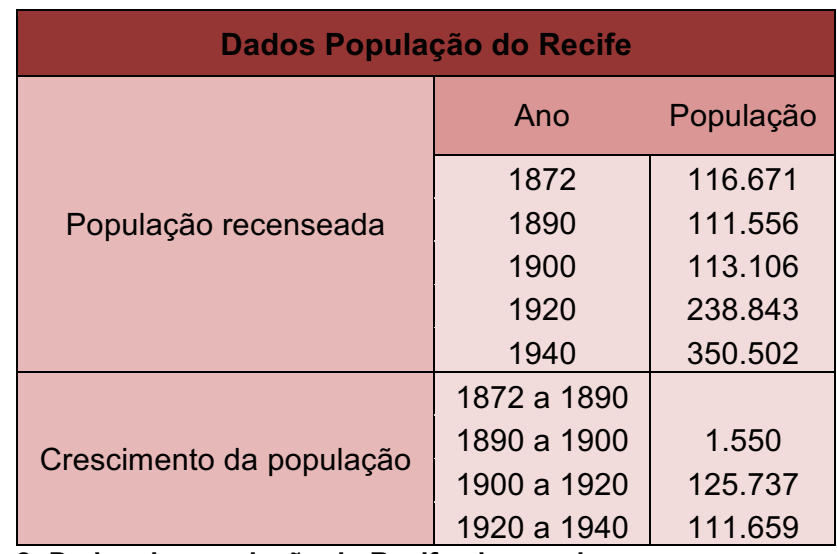

Gráfico 2: Dados da população do Recife, de acordo com os recenseamentos.

Elaboração própria a partir dos dados do Boletim da Cidade e do Porto do Recife, 1950.

É interessante avaliar a extensão física que a expansão urbana do Recife havia atingido até então. Partindo do Bairro do Recife, assumindo uma configuração radial, a ocupação da cidade se dava ao longo de cinco principais eixos: Recife/Paissandú, Recife/Afogados, Recife/ Estação de Ferro Central, Recife/Capunga e Recife/ Largo de Santo Antônio. (LUBAMBO, 1991, p.54)

Observa-se, que a cidade cresce ao longo desses eixos, que se caracterizam pelas estradas de ferro, complementadas pelas estradas de bondes de tração animal (gráfico 3). O surgimento das fábricas auxiliou na concentração e urbanização de determinados bairros que, até então, estavam localizados em áreas inseridas no contexto rural.

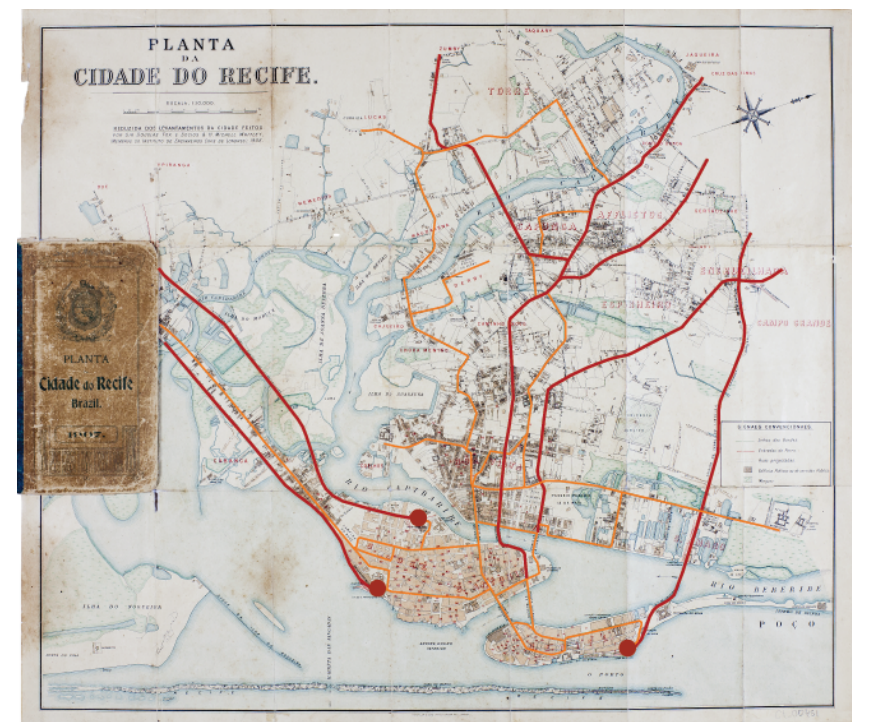

Gráfico 3: Eixos que auxiliaram na configuração urbana da cidade. Em vermelho os eixos ferroviários, que convergem para as três estações, Central, Cinco Pontas e Brum; em laranja, os percursos de bonde à tração animal.

Elaboração própria a partir da Planta da Cidade do Recife, de Douglas Fox, 1906.

Ainda no século XIX, cresce no Estado de Pernambuco, a medicina social, cujo principal objetivo era conter a proliferação das doenças que assolavam a cidade que, por sua vez, começou a ser vista como um corpo cheio de malefícios e que precisava ser sanada urgentemente. A medicina social, de acordo com Outtes (1998), se desenvolveu em paralelo com o planejamento urbano. Ganhou grande destaque, intervindo nos principais pontos da cidade mais utilizados pela população. A insalubridade seria o novo foco das políticas desenvolvidas nesta época.

Quando passa a haver por parte do Estado um interesse em organizar a população através da produção de suas condições de vida, o saber sobre a doença elaborado pela medicina aparece como se feito sob medida, adequando-se perfeitamente. [...] A implantação do projeto da medicina social passa pela ascensão dos médicos a posições no aparelho de Estado e nas entidades da sociedade civil, assim como o exercício do poder do Estado a partir do prisma da saúde passa pela cooptação dos médicos à sua estrutura (Op. Cit., 1998, p. 10). 
Assim, o desejo agora reinante no final do século XIX e princípio do XX de transformar e modernizar a cidade, afastando do centro a população mais carente, considerada imprópria para o novo panorama almejado, encontra sua base teórica na medicina social, que vem contribuir para as medidas adotadas neste período. Com base nessas diretrizes, o século XX é marcado pelas políticas de salubridade, desenvolvidas pelo engenheiro Saturnino de Brito. Esse recebeu a incumbência de realizar os projetos de reforma do porto do Recife, bem como a substituição do bairro portuário por largas avenidas e arquitetura eclética. Neste momento, a cidade é dotada de uma rede de saneamento e do modelo radial de crescimento urbano, a partir do porto.

Tanto o novo porto, como o saneamento, entravam como subterfúgios para a substituição da aparência colonial que, imposta pelo traçado das ruas e pelas antigas construções do centro histórico da cidade, deveria passar por transformações que ultrapassassem as modificações meramente cosméticas que o Período Imperial depositou nas fachadas dos antigos sobrados recifenses. [...] É neste processo de substituição de traçados e de edificações no centro histórico da cidade, além da criação de áreas de expansão, que o saneamento será implantado como um "abre alas" para novas edificações, permitindo que a arquitetura produzida naquela época encontre expressividade em todos os espaços da cidade. (Carvalho et. al, 2010, p. 20).

Impulsionados pelas modernizações propaladas pelos países europeus, bem como pela necessidade de melhoria nas condições de vida, a cidade foi sendo transformada. As ruas estreitas, o traçado irregular, sobrados sem ventilação e com alcovas, características da arquitetura colonial, eram vistos como disseminadores de doenças e dificultavam o desenvolvimento citadino.

A representação de que a cidade era suja e insalubre constituiu-se uma recorrência frequente. $O$ traçado urbano remanescente do período colonial, formado por ruas estreitas e esconsas, becos, vielas e sobrados implantados em lotes sem recuos frontais e laterais, muitas vezes com vários andares, dificultando a penetração dos raios solares e das correntes de ar, foi constantemente apontado como perigo à saúde. (Outtes, 1991, p. 4).

A nova política visava organizar a cidade, bem como remodelar os espaços urbanos, retirando dele os elementos que causavam os atrasos às modernizações, como também as moléstias que assolavam a cidade. As ruas tortuosas, o crescimento dos bairros sem planejamentos, cujas edificações eram mal iluminadas e sem ventilação, eram os principais focos desta nova política.

\subsection{O parcelamento do solo nas legislações}

O instrumento do parcelamento do solo surge como peça chave no ordenamento territorial da cidade do Recife, uma vez que, através dele houve uma distribuição dos lotes, das quadras, dos equipamentos comunitários e das vias públicas, organizando de uma melhor forma a estrutura espacial do novo tecido urbano, permitindo seu desenvolvimento.

Em 1839, com o início do processo de modernização e de expansão da cidade colonial, as determinações legislativas contêm recomendações de redesenho das quadras como modo de corrigir as irregularidades do traçado existente, além de estipular largura mínima para as novas ruas: $16,98 \mathrm{~m}$ para as principais e $11,32 \mathrm{~m}$ para as secundárias. Posteriormente, a Lei n.4 de 1893 adota características higienistas, como consequência das discussões sanitaristas da época. São estipuladas a dimensão da largura e altura das fachadas em relação à rua. A altura máxima estabelecida era de três pavimentos; o lote era estreito e comprido, permitindo maior densidade nas áreas centrais, diferentemente dos lotes do subúrbio, que eram mais generosos. Observa-se uma total desvinculação da edificação em relação ao espaço da rua, no perímetro central, que dizia respeito aos edifícios públicos. Após essa lei o sistema viário passa a ser hierarquizado, constituindo um novo desenho para a cidade.

Com o Regulamento de 1919, adota-se, pela primeira vez, a lógica do zoneamento, diferenciando os perímetros e ocupação do solo, onde a cidade passa a ser dividida em quatro zonas: primeiro perímetro ou principal; segundo perímetro ou urbano; terceiro perímetro ou suburbano; quarto perímetro ou rural. Há uma configuração da cidade a partir do modelo radioconcêntrico, com um centro densamente construído e habitado, além de dotado das principais atividades urbanas, aproveitando a infraestrutura existente. Destaca-se o crescimento das zonas urbanas e suburbanas estendidas pelo rio Capibaribe, que tinham como eixos principais as avenidas Caxangá e Estrada do Arraial que, de acordo com Reynaldo (2017), foram elencadas como radiais potentes para o crescimento periférico.

Há uma hierarquia espacial apoiada na expansão urbana pelo oeste. As casas nas áreas urbanas, suburbanas e rurais permanecem isoladas no lote, onde se respeitam os princípios higienistas de Saturnino 
de Brito, como a necessidade de ventilação e iluminação, através da abertura de janelas. O bloco deveria ser alinhado e isolado no lote, contribuindo para uma hierarquia da tipologia no território (Op. Cit). No perímetro central os recuos das edificações continuavam proibidos, garantindo o bloqueio a construções fora do alinhamento, configurando a tipologia da área central, predominantemente composta por sobrados.

Assim, o Regulamento de 1919 se caracteriza especialmente pela adoção da lógica do zoning (gráfico 4) como estratégia de organização espacial, o que modificará o desenho da cidade nos próximos anos. A legislação, no entanto, não estabelecia os locais de moradia proletária, devido à ausência de uma política habitacional. Assim, observa-se que até este momento não se falava sobre o parcelamento do solo como instrumento de ordenamento territorial.

O parcelamento do solo começa a ser utilizado como instrumento na cidade, a partir do Regulamento de 1932, que define por meio da regulamentação dos loteamentos, as condições da trama urbana da expansão do Recife. Observa-se na normativa, particular ênfase quanto às condições tipológicas. $O$ regulamento adota o caráter de cidade jardim, que pode ser observado na recomendação da "supressão dos muros divisórios nos novos bairros, facultando o estabelecimento da divisa do lote por meio de cercas vivas" (art.5, parágrafo 15) ou, ainda, na definição das condições para que um loteamento possa ser considerado como projeto de uma cidade ou de bairro jardim (Op. Cit, 2013).

Esse regulamento, no entanto, é logo substituído em 1936, que mantém as mesmas características para os loteamentos, com exceção das cidades/bairros jardins. O loteamento passa a ser o instrumento de ordenamento da expansão urbana da cidade, consolidando em definitivo as áreas do antigo traçado como centro da organização urbana, e espaço terciário por excelência e ampliando a singularidade da construção isolada no terreno como tipologia da expansão urbana (Op. Cit). A lógica do zoneamento permanece (gráfico 5), com modificação, apenas, dos limites das áreas das zonas, que continuam denominadas como principal, urbana, suburbana e rural. Entretanto, são acrescidos novos elementos que auxiliam na nova organização urbana, como a categorização funcional e a delimitação dos centros secundários, que contabilizam doze, fragmentado nas áreas periféricas da cidade.

O centro urbano [...] perdia o protagonismo de único espaço comercial da cidade: doze áreas centrais secundárias, distribuídas nas zonas urbana e suburbana, foram propostas no Regulamento de construção de 1936, que também propunha a mistura do comércio e da residência nos centros comerciais e a hegemonia da residencial nos demais âmbitos: estava vedado o uso comercial nos setores residenciais ou onde coubesse o edifício isolado. (REYNALDO, 2017, p. 142)

Assim, observa-se um fortalecimento da hierarquia do território, trazidas anteriormente pela legislação de 1919. A setorização e hierarquia dessas áreas dificultava solucionar as carências à moradia pela população de baixa renda, uma vez que essa população era deslocada para áreas menos valorizadas e mais distantes do centro urbano principal, onde se desenvolviam as principais atividades. Além das subzonas comerciais e residenciais, destaca-se a regulamentação das zonas industriais localizadas na terceira zona ou suburbana.

O Regulamento de Construções de 1936 é substituído pelo Código de Urbanismo e Obras de 1961, que insere oficialmente as zonas industriais na cidade, totalizando 5; além da delimitação e consolidação das zonas portuárias, duas; centros comerciais, que totalizam quatro; uma zona universitária; e o restante do território englobado no zoneamento, como zona residencial (gráfico 6). 


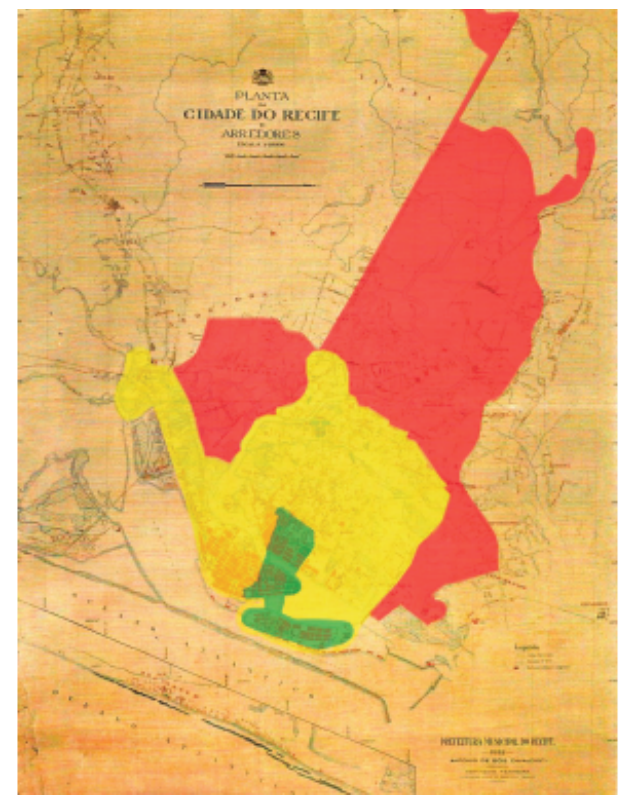

Gráfico 4- Planta da cidade do Recife com zoneamento de 1919. Em verde a zona principal, em amarelo a zona urbana e em vermelho a zona suburbana.

(REYNALDO, 2017.)

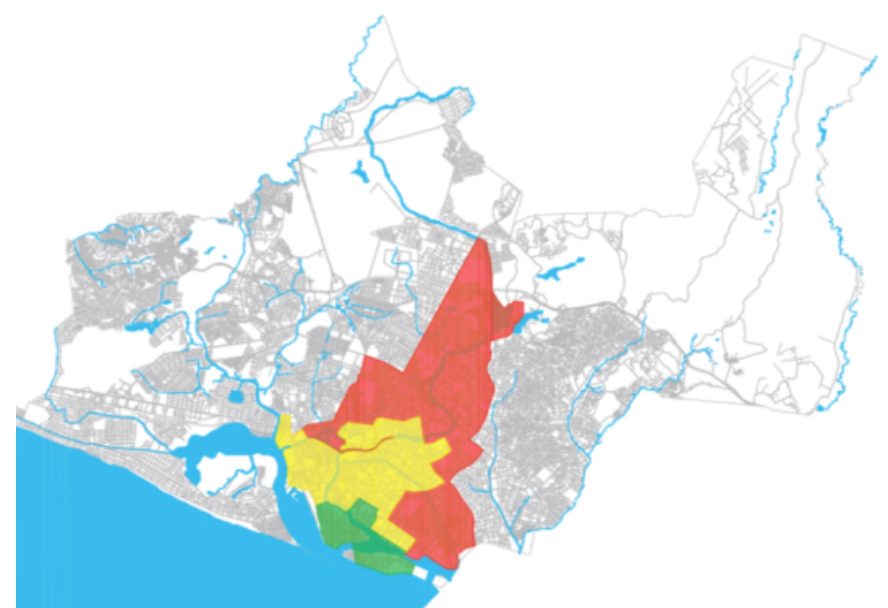

Gráfico 5- Planta da cidade do Recife com zoneamento de 1936. Em verde a zona principal, em amarelo a zona urbana e em vermelho a zona suburbana. As áreas não incorporadas ao polígono corresponde a zona rural.

(Laboratório das Paisagens Culturais, 2017.)

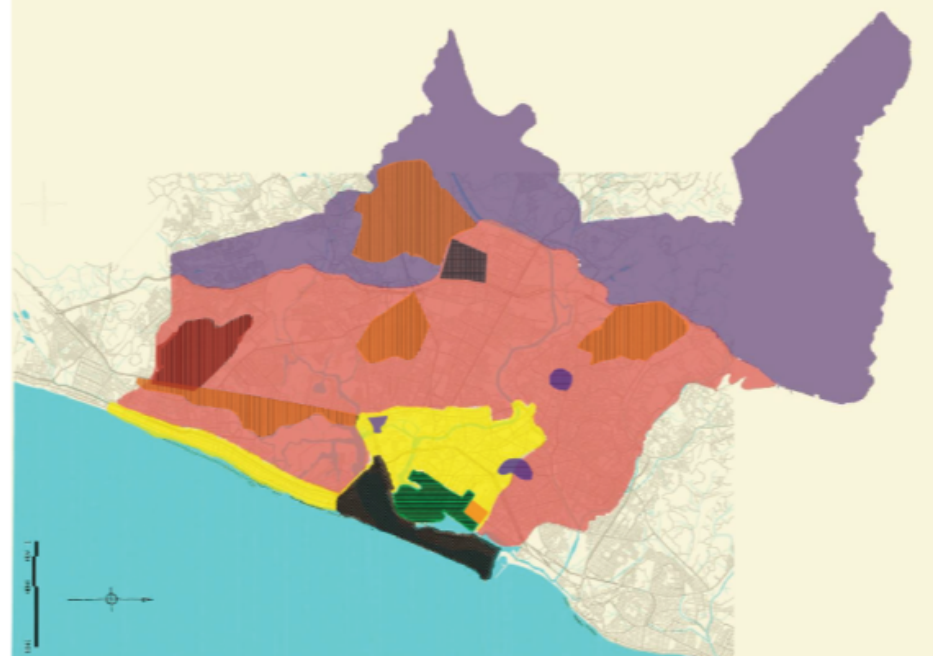

Gráfico 6- Planta do Recife com zoneamento de 1961. Em verde a zona principal, em amarelo a zona urbana, em vermelho a zona suburbana, e em lilás a zona rural. Observa-se ainda, zona industrial em laranja, zona portuária em preto e vermelho escuro, zona comercial em roxo.

Elaboração própria a partir de REYNALDO, 2017. 
Com as novas diretrizes e o novo zoneamento, parte das antigas áreas destinadas a residências são incorporadas às zonas industriais ou as zonas comerciais, permitindo a construção de equipamentos públicos e privados e retirando o espaço de antigas habitações, especialmente às destinadas a população de baixa renda, como ocorreu no bairro de Santo Amaro, então zona suburbana, que teve grande parte do seu solo composto por habitações populares e foram substituídas paulatinamente, pelas áreas destinadas às universidades, fábricas, galpões e instituições públicas e particulares.

\subsection{As políticas habitacionais e a "cidade popular"}

Não havia, até meados dos anos 1920, uma política habitacional, não só no Recife, como no Brasil como um todo. O Estado era completamente ausente na produção da moradia e na regulamentação do mercado de locação (Bonduki, 2011). Até o início do século XX, muitas cidades brasileiras eram marcadas pela forte presença de cortiços e dos mocambos. Quando esses se tornavam obstáculos à renovação urbana das áreas mais nobres da cidade, eram demolidos e a "massa sobrante" deslocada para as regiões menos valorizadas pelo mercado (Villaça, 2001).

A produção habitacional no Brasil, até início do século XX, esteve volta prioritariamente, para o investimento privado, em moradias de aluguel. Não havia uma preocupação por parte do Estado quanto ao direito de moradia. $\mathrm{O}$ quadro era marcado por forte demanda habitacional nas principais cidades, ao passo que se tornava rentável a produção de casas de aluguel com baixo investimento, sem infraestrutura adequada (Bonduki, 1982).

No ano de 1925 existiam no Recife cerca de, 19.079 casas frente a 19.947 mocambos. Em 1939, os mocambos chegam a número de 45.521, de acordo com a Comissão Censitária de 1938. Do total, 19.486 eram próprios, porém com chão alugado, 19.514 alugados e apenas 6.581 eram proprietários do terreno e do mocambo. Essas habitações passaram a serem vistas como um ferimento a vaidade de uma sociedade moderna, que almejava o crescimento e a modernização da cidade, além de se tornarem um empecilho ao desenvolvimento econômico.

Sendo assim, no ano de 1939 o interventor do Estado de Pernambuco, Agamenon Magalhães, preocupado com a estética da cidade, bem como o crescimento desenfreado de pessoas ligadas ao Partido Comunista, inicia uma campanha denominada de Cruzada Social Contra o Mocambo, criando a Liga Social contra o Mocambo, entidade privada cuja finalidade era promover a extinção deste tipo de moradia e incentivar a construção de casas populares.

A Liga Social Conta o Mocambo (LSCM), aliado ao Regulamento de Construções de 1936, contribui para um ordenamento territorial pautado no parcelamento do solo com características populares e na criação de habitações destinadas a assistência social e a operários sindicalizados e contribuintes, de acordo com os dados do Relatório da Liga Social Contra o Mocambo, de 1939.

O plano da Liga Social Contra o Mocambo visa, sobretudo, à reeducação de ex-habitantes dos miseráveis casebres erguidos na lama do mangue. Nas vilas, obras de educação e assistência têm a tarefa de reajustá-los aos padrões de vida exigidos pela dignidade humana e para o seu próprio aperfeiçoamento profissional. Se o mocambo transige com a moral e rebaixa o espírito, a vila popular exige que as normas morais sejam observadas e que o seu morador procure adquirir a consciência do seu próprio valor e do papel que lhe cabe na vida social. (DEPARTAMENTO ESTADUAL DE IMPRENSA, 1943, p.9)

Atua até 1945 sendo substituída pelo Serviço Social Contra os Mocambos (SSCM), que possuía os mesmos objetivos. O crescimento populacional e a grande aprovação dos loteamentos da cidade ocorrem justamente no período de atuação do SSCM, entre as décadas de 1940 e 1950, de acordo com os dados dos 1.798 loteamentos aprovados pela Prefeitura da Cidade do Recife. Até o presente momento, dos 300 loteamentos populares catalogados, cerca de 200 são regidos pelo Regulamento de Construções de 1936 e 100 pelo Código de Urbanismo e Obras de 1961. 


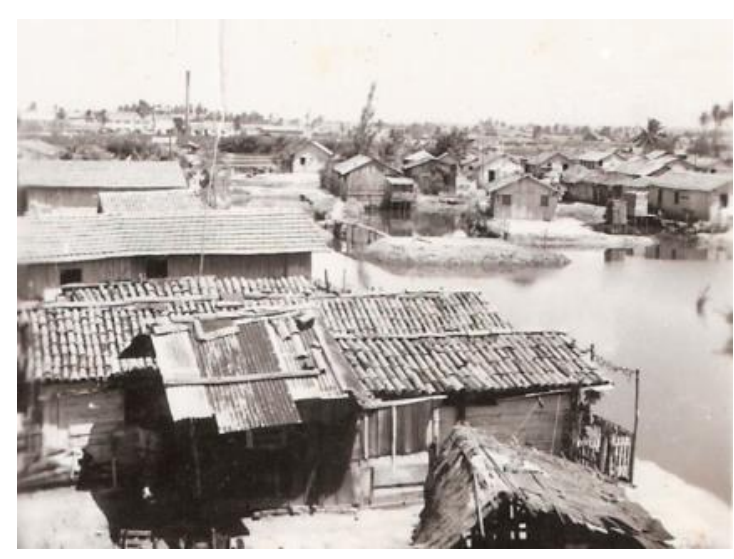

Gráfico 7: Panorama dos mocambos no Recife. (Museu da Cidade do Recife)

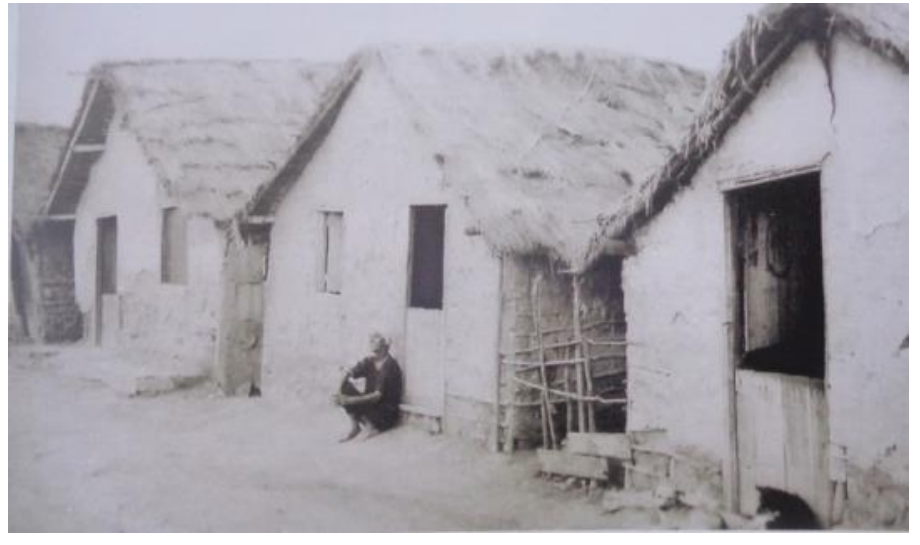

Gráfico 8: Mocambos do Recife.

(Fundação Joaquim Nabuco)

Fundada em 1939, a LSCM, possuía "caráter humanitário, destinada a promover a extinção desse tipo de moradia e incentivar a construção de casas populares, dotadas de condições higiênicas e de fácil aquisição" (PERNAMBUCO, 1940), sendo a primeira instituição pública criada durante a presidência de Getúlio Vargas, para construção de casas populares, mesmo que, em seu estatuto fosse caracterizada como uma sociedade de direito privado e não constasse no corpo criador e de diretores o nome do interventor Agamenon Magalhães.

Além da construção das casas e da demolição dos mocambos, livrando a cidade das chagas as quais essas habitações eram consideradas, a Liga teve sua atuação intimamente ligada ao processo de aterramento dos alagados e mangues na cidade do Recife, que de acordo com Bonduki (2014, p. 293),

O aterro dos mangues era o instrumento mais eficaz para afastar os mocambos do "perímetro principal da urbs", objetivo que várias disposições legais não haviam conseguido. As campanhas publicitárias enfatizavam as propostas de grandes planos de aterros e a expansão das obras de saneamento, que conquistavam a adesão da opinião pública e serviam de justificativa para as interdições e demolições nos mocambos.

A proibição da construção dos mocambos em áreas centrais, mas sua permanência em áreas mais distantes, assim como as diretrizes para o parcelamento do solo destinado às vilas populares, que ficaria sobre a responsabilidade direta das instituições responsáveis pela sua construção, comprova a legitimidade da nova política de controle social e habitacional promovida pelo Estado, caracterizado pelas suas bases segregadoras, que fragmentam o espaço e afastam a população de baixa renda das áreas mais valorizadas. Esse controle é materializado no espaço através dos loteamentos populares e dos programas habitacionais, que culminaram num ordenamento territorial, em partes, voltados para população de baixa renda.

É através das legislações urbanísticas, especialmente o Regulamento de Construções de 1936, que o Estado lança as bases legais de intervenção no espaço urbano, removendo os mocambos das áreas mais valorizadas e expulsando-os para as áreas mais suburbanas, longe do centro principal. De acordo com os dados do Relatório da Liga Social Contra o Mocambo, de 1941, o Estado ainda levou parte da "massa sobrante" não absorvida pela sociedade, denominados como "indivíduos inválidos ou mendigos que vivem de caridade pública", para o interior do Estado, onde eram fornecidos, por parte do poder público, passagens de ônibus para tais lugares.

\begin{tabular}{|l|r|l|}
\hline $\begin{array}{l}\text { Instituição } \\
\text { Financiadora }\end{array}$ & $\begin{array}{l}\text { Casas em } \\
\text { construção }\end{array}$ & $\begin{array}{l}\text { Casas } \\
\text { construídas }\end{array}$ \\
\hline LSCM & 709 & 688 \\
\hline $\begin{array}{l}\text { Cotonifício } \\
\text { Bezerra de Melo }\end{array}$ & 616 & 700 \\
\hline $\begin{array}{l}\text { Empresa Construtora de } \\
\text { Casas Populares S.A }\end{array}$ & 19 & 255 \\
\hline
\end{tabular}




\begin{tabular}{|c|c|c|}
\hline $\begin{array}{l}\text { Tecelagem de Sêda e } \\
\text { Algodão de Pernambuco } \\
\text { S.A }\end{array}$ & & 277 \\
\hline $\begin{array}{ll}\text { Instituto dos } \\
\text { Comerciários }\end{array}$ & & 486 \\
\hline Instituto dos Industriários & & 50 \\
\hline $\begin{array}{l}\text { Caixa de Acidentes dos } \\
\text { Servidores do Estado }\end{array}$ & 12 & 16 \\
\hline \begin{tabular}{lr} 
Instituto & de \\
Aposentadoria & dos \\
Trabalhadores & em \\
\multicolumn{2}{l}{ Transportes e Carga } \\
\end{tabular} & & 164 \\
\hline Instituto dos bancários & & 133 \\
\hline $\begin{array}{l}\text { Caixa de Aposentadoria } \\
\text { e Pensões dos } \\
\text { Funcionários da Great } \\
\text { Western }\end{array}$ & 14 & 120 \\
\hline $\begin{array}{l}\text { Instituto de Previdência } \\
\text { dos Servidores do } \\
\text { Estado }\end{array}$ & 108 & 119 \\
\hline Instituto dos Marítimos & & 48 \\
\hline $\begin{array}{l}\text { Caixa de Aposentadoria } \\
\text { e Pensões dos Serviços } \\
\text { Públicos de Pernambuco }\end{array}$ & & 1.144 \\
\hline Grupos Particulares & & 462 \\
\hline Total & 1478 & 4662 \\
\hline
\end{tabular}

Gráfico 9: Dados das habitações construídas e em construção, até 1944, na cidade do Recife.

Elaboração própria a partir dos dados do Relatório da LSCM, de 1944.

O grande crescimento urbano, atrelado ao parcelamento do solo destinado a população de baixa renda, como visto, foi impulsionado pela LSCM, que até 1945 foi a grande responsável pelo provimento de moradias na cidade do Recife, atuando mais fortemente nos aterros e no incentivo aos industriais e a particulares, na construção de casas populares para venda ou aluguel. (gráfico 9, 10 e 11)

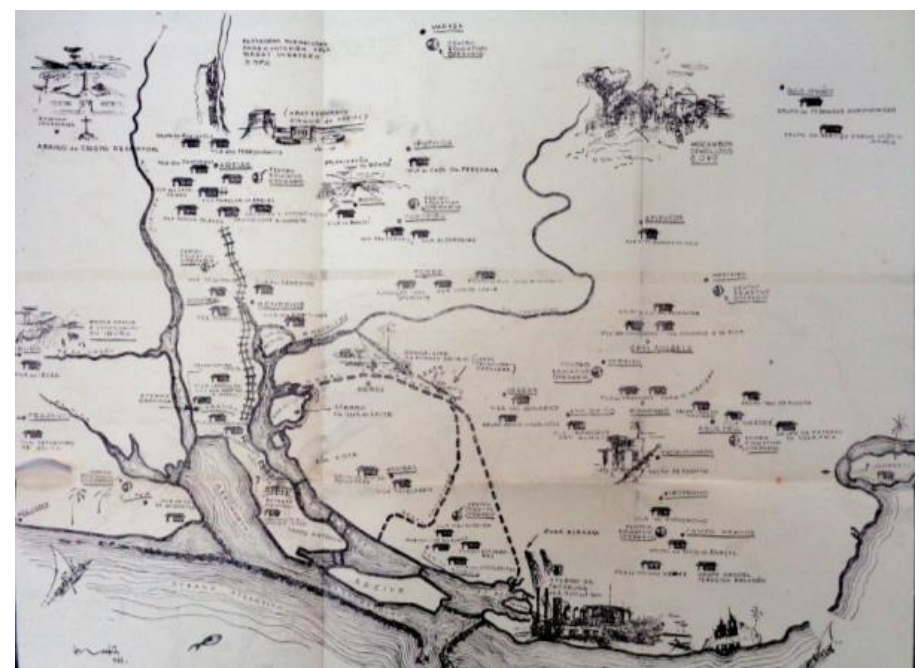

Gráfico 10: Localização das vilas populares construídas pela LSCM.

(Relatório da Liga Social Contra o Mocambo, 1942.) 


\begin{tabular}{|l|l|l|}
\hline Áreas aterradas & \multicolumn{1}{l}{ Aterro } & \multicolumn{1}{l|}{ Área } \\
\hline Santo Amaro & $435.772,30 \mathrm{~m} 3$ & $306.614,4 \mathrm{~m} 2$ \\
\hline Gameleira & $82.690 \mathrm{~m} 3$ & $87.785 \mathrm{~m} 2$ \\
\hline Avenida Saudade (Rua da Aurora) & $22.562,70 \mathrm{~m} 3$ & $22.000 \mathrm{~m} 2$ \\
\hline
\end{tabular}

Gráfico 11: Áreas aterradas pela LSCM até 1944 em Santo Amaro, Gameleira e Rua da Aurora.

Elaboração própria a partir dos dados do Relatório da LSCM, de 1944.

No primeiro momento, as Ligas detiveram-se na demolição dos mocambos. A intenção do governo era erradicar os mocambos da cidade a todo custo. Limpar a cidade não só pelo embelezamento, mas atendendo a outros interesses, como a abertura da área ocupada pelos mocambos ao mercado imobiliário (ALVES, 2009). Os mocambeiros foram, assim, empurrados para os limites do Recife. A campanha teve início nas zonas onde seriam construídas as vilas populares, conjunto de casas destinadas a melhores habitações e com melhores infraestrutura e condição de vida. Posteriormente, o processo de derrubamento seguiu para os subúrbios. Essa política caracterizou toda a década de 1940 e parte da década de 1950. Nos anos subsequentes observa-se uma nova produção de moradias, agora regidas especialmente pelo governo federal, pelo Banco Nacional de Habitação.

O Banco Nacional de Habitação (BNH), criado pela Lei $n^{\circ} 4.380$, de 21 de agosto de 1964, instituído pelo Plano Nacional de Habitação, tinha como objetivo promover a construção e aquisição da casa própria, especialmente pelas classes de menor renda, bem como a ampliar as oportunidades de emprego e dinamizar o setor da construção civil (Valadares: s/d). Além do BNH, destaca-se a produção das Companhias de Habitação (COHAB) e das INOCOOPS- Cooperativas Habitacionais.

No Recife, segue-se a lógica do zoneamento, adotado pelo Código de Urbanismo e Obras de 1961, que aplica os conceitos funcionalistas sobre os edifícios, estipulava o novo zoneamento da cidade: urbano, suburbano e rural, que se subdividem em zonas comerciais, zonas portuárias, zonas industriais, zonas universitárias, zonas de reservas florestais e zonas non aedificandi, com subdivisões em núcleos, com todas as implicações que isso representa em termos de valor do solo. Essa legislação fornecerá as bases para o novo desenho dos loteamentos populares e das novas habitações.

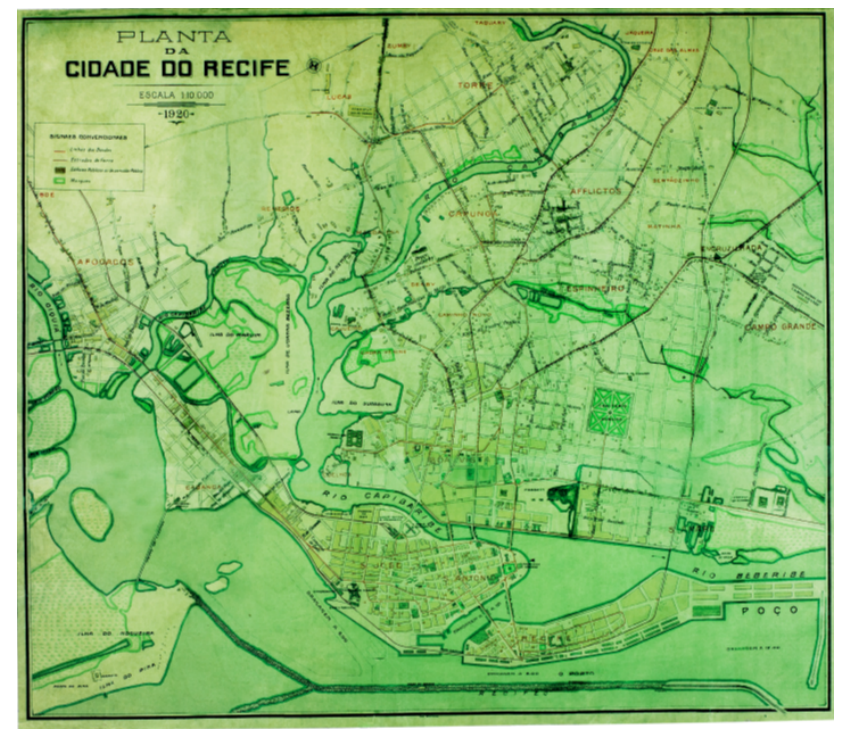

Gráfico 12: Planta da cidade do Recife em 1920 marcada pelos alagados e significativo crescimento urbano. (IPHAN)

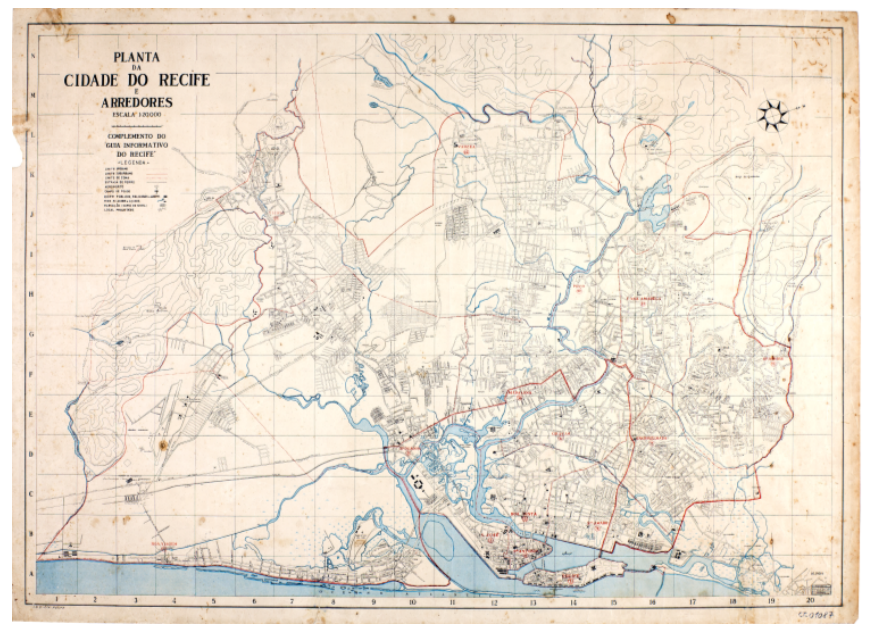

Gráfico 13: Planta da cidade do Recife da década de 1950, após processo de aterro, com grande crescimento da mancha urbana.

(IPHAN) 


\section{AS LEGISLAÇÕES URBANÍSTICAS E O DESENHO DA CIDADE}

\subsection{Os regulamentos no desenho da cidade}

As legislações urbanísticas contribuem fortemente para a formação das cidades, sendo através delas que o Estado regulamenta o ordenamento territorial, fornecendo bases para a construção de uma cidade acessível a toda população. No Recife, o primeiro instrumento que regulamenta a expansão da cidade é o Regulamento de 1919, que é substituído pelo de 1932, onde este último vigora apenas até 1936, quando é aprovado o novo Regulamento de Construções, que fornecerá as bases para a grande expansão urbana da cidade.

No entanto, o desenho da cidade já era delineado, como já visto, pelas legislações do século XIX, que baseado nos preceitos sanitaristas, forneciam bases de desenhos, estipulando os alinhamentos das edificações e das ruas, altura e largura das fachadas relacionadas a largura da rua, ocupação dos lotes de acordo com a área em que tivesse situado. Essas características se tornaram ainda mais claras com o Regulamento de 1919, quando se passou a exigir mudança nos parâmetros construtivos e do traçado urbano.

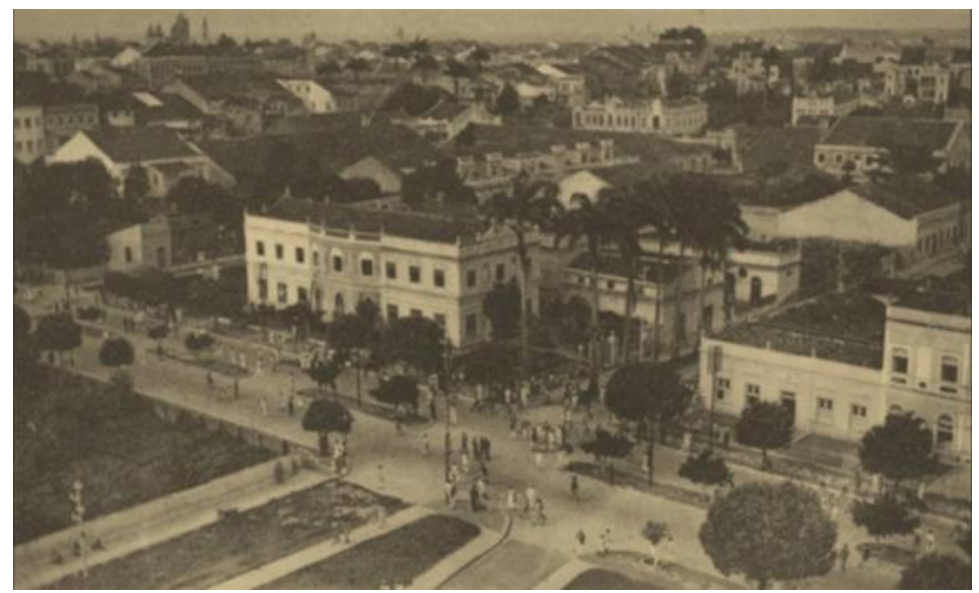

Gráfico 14: bairro da Boa Vista com destaque para o alinhamento da rua e as tipologias de casas térreas e sobrados, início do século $X X$.

(Museu da Cidade do Recife)

O Regulamento de 1919 (lei n 1.051) é o primeiro instrumento que normatiza a ocupação do Recife através da delimitação da zona central e da definição da inadequação da figura do sobrado como habitação nas demais zonas da cidade (Reynaldo, 2013), ficando estipuladas as construções isoladas no lote como modelo edificatório.

Em 1932 é aprovado o novo Regulamento de Construções, em terrenos dotados de arruamento, segue a mesma lógica da legislação anterior, diferindo no regulamento dos loteamentos, nas condições da expansão urbana do Recife e, consequentemente, o terreno capaz de receber a habitação idealizada na normativa de 1919. A normativa enfatiza as condições tipológicas, definindo que somente as construções comerciais serão permitidas no alinhamento das ruas e que todos os demais prédios deverão ficar recuados desse limite. Salienta-se a influência das discussões internacionais das cidades jardins, que influencia a lei e a mesma recomenda a supressão de muros divisórios nos novos bairros, facultando o estabelecimento da divisa do lote por meio de cercas vivas. Além disso, define as condições para que o loteamento se caracterize como um bairro jardim.

Em 1936 o antigo Regulamento de Construções é substituído. Elaborado a partir dos estudos realizados pelo Clube de Engenharia e de sugestões propostas pelo arquiteto Atílio Corrêa Lima, esse regulamento divide a cidade em quatro zonas: primeira ou principal; segunda ou urbana; terceira ou suburbana; quarta ou rural. Além do zoneamento, são fornecidos parâmetros para o parcelamento do solo e para as novas edificações, que agora deveriam seguir os preceitos do higienismo, propalado principalmente no início do século $X X$.

Estabelece os regulamentos de uso e ocupação do solo, aperfeiçoando os requisitos de iluminação e ventilação das edificações, estabelecendo recuos mínimos diferenciados para cada ambiente interno da 
construção. Mantém as mesmas condições definidas para os loteamentos, exceto quanto à abordagem das características das cidades ou bairros jardins. O decreto consolida em definitivo as áreas do antigo traçado como centro da organização urbana e espaço terciário por excelência, podendo sua tipologia reproduzir-se sempre quando o uso é o não residencial e amplia a singularidade da construção isolada no terreno como tipologia da expansão urbana (Reynaldo, 2013). Os novos padrões de parcelamento do solo privilegia uma expansão urbana horizontal, além de hierarquizar e estrutura o sistema viário de modo a facilitar a circulação e a velocidade.

\begin{tabular}{|c|c|c|c|c|c|c|}
\hline \multirow{2}{*}{$\begin{array}{c}\% \text { áreas } \\
\text { públicas }\end{array}$} & \multicolumn{2}{|c|}{ Dimensão das quadras } & \multicolumn{2}{|c|}{$\begin{array}{c}\text { Dimensão lote } \\
\text { (largura/superfície) }\end{array}$} & \multicolumn{2}{c|}{ Rua } \\
\cline { 2 - 7 } & Zona Urbana & $\begin{array}{c}\text { Zona } \\
\text { Suburbana }\end{array}$ & Zona Urbana & Zona Suburbana & Largura & Calçada \\
\hline 40 & $60 \times 150 / 200 \mathrm{~m}$ & $80 \times 200 \mathrm{~m}$ & $\begin{array}{c}8 \mathrm{~m} / 200 \mathrm{~m}^{2} \text { (comércio) } \\
12 \mathrm{~m} / 360 \mathrm{~m}^{2} \\
\text { (residência) }\end{array}$ & $12 / 480 \mathrm{~m}^{2}$ & $\begin{array}{c}15 \mathrm{~m} \\
10 \mathrm{~m}\end{array}$ & $02 / 05$ \\
\hline
\end{tabular}

Gráfico 15: Parâmetros urbanísticos de acordo com o Regulamento de Construções de 1936.

Elaboração própria a partir da legislação citada.

Como visto, o Regulamento de Construções de 1936 fornece os parâmetros de desenho, como ocupação do terreno, índices de intensidade de uso do solo e afastamentos progressivos da edificação em relação às divisas do terreno (Medina, 1997). No entanto, não trazia nada específico sobre os loteamentos e habitações populares, relatando apenas que tais loteamentos só deveriam ser aceitos quando apresentados por particular, empresa ou sociedade que se obriguem a fazer as edificações, devendo apresentar vários tipos habitacionais. Sobre as vilas operárias, revela em seu artigo 217 que, essas vilas serão locadas nas circunvizinhanças dos estabelecimentos industriais situadas nas subzonas previstas no referido Regulamento.

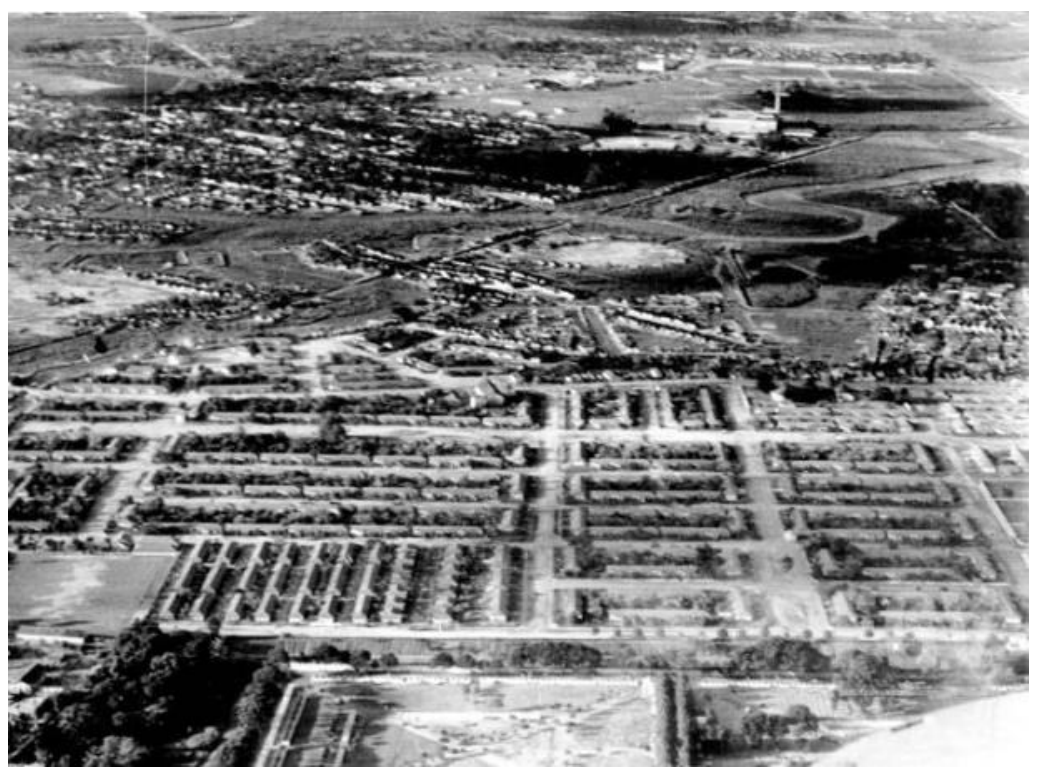

Gráfico 16: Imagem de loteamentos populares elaborados pela Liga Social Contra o Mocambo, entre o final da década de 1930 e princípios da década de 1940, no bairro de Santo Amaro.

(CPDOC- Fundação Getúlio Vargas)

Com a atuação das LSCM, as vilas populares construídas até 1945 ficaram sob responsabilidade dessa instituição, onde a mesma, respeitando alguns dos parâmetros gerais, como a largura das vias e o tamanho das calçadas, realizava todo o desenho do loteamento popular, além de prover os desenhos das habitações, que de acordo com o Regulamento em vigor, deveria apresentar diversas tipologias de plantas habitacionais.

Com base na visão de um Recife Metropolitano, tendo como pressuposto um planejamento regional, defendido por Antônio Bezerra Baltar em seu trabalho intitulado "Diretrizes de um Planejamento Regional para o Recife", publicado em 1951, o novo Código de Urbanismo e Obras (C.U.O), aprovado pela Lei n. 
7.427, em 1961, é a nova legislação que rege o crescimento urbano da cidade a partir da década de 1960. A legislação traz minuciosas diretrizes que seguiam conceitos funcionalistas, ainda com a ideia do zoning, onde a cidade é, agora, dividida em dois setores principais, o primeiro setor (urbano) e o segundo setor (suburbano). Esses setores se subdividiam em zonas comerciais, residenciais, industriais, universitárias e portuárias.

\begin{tabular}{|c|c|c|c|c|c|c|}
\hline \multirow{2}{*}{$\begin{array}{l}\% \text { áreas } \\
\text { públicas }\end{array}$} & \multicolumn{2}{|c|}{ Dimensão das quadras } & \multicolumn{2}{|c|}{$\begin{array}{c}\text { Dimensão lote } \\
\text { (largura/superfície) }\end{array}$} & \multicolumn{2}{|c|}{ Rua } \\
\hline & Zona Urbana & Zona Suburbana & Zona Urbana & Zona Suburbana & Largura & Calçada \\
\hline $\begin{array}{l}35 \\
50\end{array}$ & \multicolumn{2}{|c|}{$50 \times 80 / 250 m$} & $12 / 300 m$ & $12 / 360 \mathrm{~m}$ & $\begin{array}{c}21 \mathrm{~m} \\
\text { ou } 18 \mathrm{~m} \\
12 \mathrm{~m}\end{array}$ & $01 / 03$ \\
\hline
\end{tabular}

Gráfico 17: Parâmetros urbanísticos de acordo com o Código de Urbanismo e Obras de 1961.

Elaboração própria a partir da legislação citada.

No que concerne os loteamentos populares, as dimensões das quadras na direção normal às ruas transversais seria de, no mínimo, 40m. Nesses loteamentos não seria necessário: (i) colocação de meio fio e linha d'água em todas as ruas, (ii) iluminação dos logradouros, (iii) rede de abastecimento de água, (iv) arborização dos logradouros, respeitadas as determinações do Departamento de Engenharia e Obras.

Os lotes populares eram permitidos nos setores suburbanos, destinados especialmente a construções geminadas, com as dimensões mínimas de $14 \mathrm{~m}$ de testada e $350 \mathrm{~m}^{2}$ de comprimento, para cada lote. De acordo com o inciso $2^{\circ}$ do artigo $98^{\circ}$ da lei, eram permitidos no setor suburbano, loteamentos de terrenos para construção de casas em série, quando apresentado o plano de conjunto para construção imediata, não podendo ultrapassar o número de seis para cada série e devendo ser julgado pelo Departamento de Engenharia e Obras. Esses loteamentos, mesmo no setor suburbano, não poderiam ser localizados ao longo de praças, avenidas ou ruas principais já existentes ou projetadas. O Código proibia, ainda, o loteamento em terrenos baixos, alagadiços ou sujeitos a inundações, sem que fossem previamente aterrados e realizados os "grades" estabelecidos pela Prefeitura.

Sobre as habitações populares, o Código dispõe de um capítulo que fornece as bases para tal tema. Onde no primeiro artigo, de número 783 , ele afirma que só poderão ser construídas nas Zonas Residenciais e Núcleos Residenciais do Setor Suburbano e no Setor Rural; possuir apenas um pavimento e ocupar $40 \%$ do lote, sem ultrapassar $100 \mathrm{~m}^{2}$. As habitações isoladas no lote deveriam ser construídas de alvenaria, mista, madeira ou outro material adequado a juízo do Departamento de Engenharia e Obras; e as geminadas apenas de alvenaria.

As casas em série deveriam ter uma largura de, no máximo, $6 \mathrm{~m}$, onde a separação das unidades habitacionais seria realizada através de muro divisório, sem que disso pudesse resultar a possibilidade de efetuar desmembramento. Foram previstos, também, blocos residenciais, cujo terreno deveria possuir, no máximo, $50 \mathrm{~m}$ de profundidade, os blocos deveriam ocupar no máximo $40 \%$ da área total do terreno, sendo proibida a construção de muros entre os blocos, exigindo-se, ainda, a construção de reservatórios de distribuição de água com capacidade equivalente a 150 litros por dormitório.

\subsection{Os loteamentos populares}

Após análise das legislações urbanísticas que dispõem os parâmetros de desenho para expansão urbana da cidade, podemos observar a ausência pelo Regulamento de Construções de 1936, de parâmetros específicos para o parcelamento do solo direcionado a população de baixa renda, assim como diretrizes específicas das habitações. A preocupação com os mocambos ocorreu mais no âmbito do controle social e da modernização da cidade, do que como política habitacional que tinha por objetivo fornecer à população mais carente o direito à moradia. A construção das casas entre as décadas de 1940 e 1950 jamais chegou ao número dos mocambos demolidos e da população que foi relocada, se instalando, em sua maioria, nas áreas de morro.

Com base nos parâmetros estipulados pelo Regulamento de 1936, verificou-se uma forte aprovação de plantas de loteamentos que, embora não fossem reconhecidas como loteamentos populares, eram locadas 
no subúrbio da cidade, com dimensões de lotes e quadras bem menores do que as estipuladas pela legislação.

No âmbito da política adotada pela Liga Social Contra o Mocambo, observa-se a construção de um maior número de vilas populares no bairro de Santo Amaro (gráfico 18 e 19), localizado na década de 1940 e 1950, na zona suburbana da cidade, marcado, até então, pela grande quantidade de alagados e mocambos, cujas vilas possuíam características distintas pelo tamanho de quadras e lotes, possuindo em comum apenas o tipo habitacional adotado.

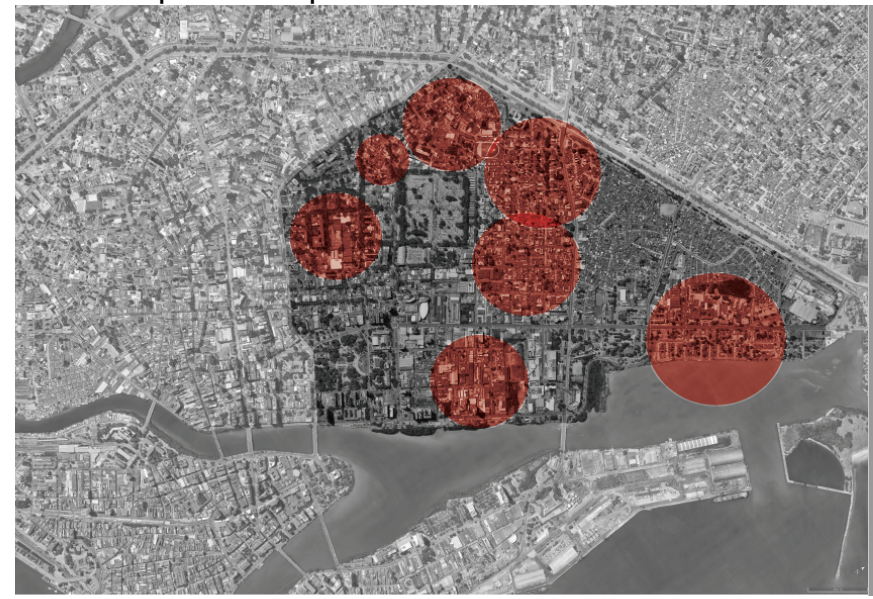

Gráfico 18: Localização das vilas populares criadas no bairro de Santo Amaro pela LSCM e por particulares.

Elaboração própria a partir das plantas de loteamentos do bairro.

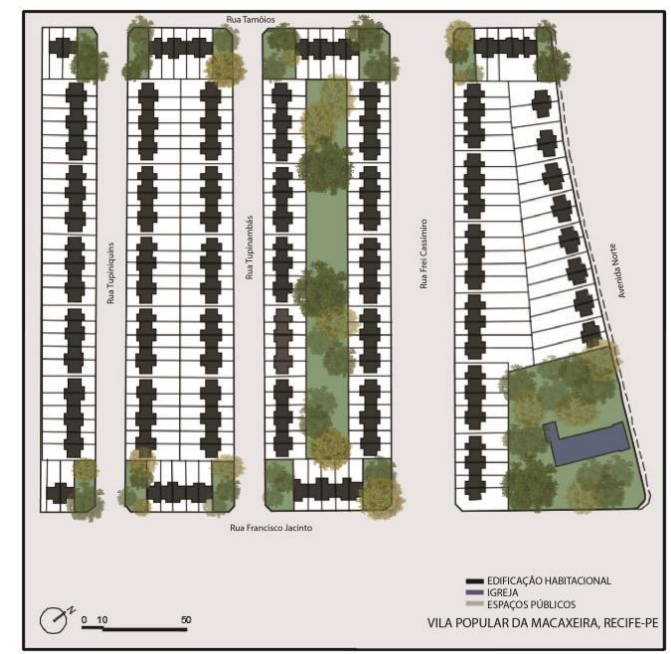

Gráfico 20: Planta de loteamento desenhada a partir da planta original da vila da Macacheira, com ênfase nas habitações e nos espaços livres.

Elaboração própria a partir de planta original

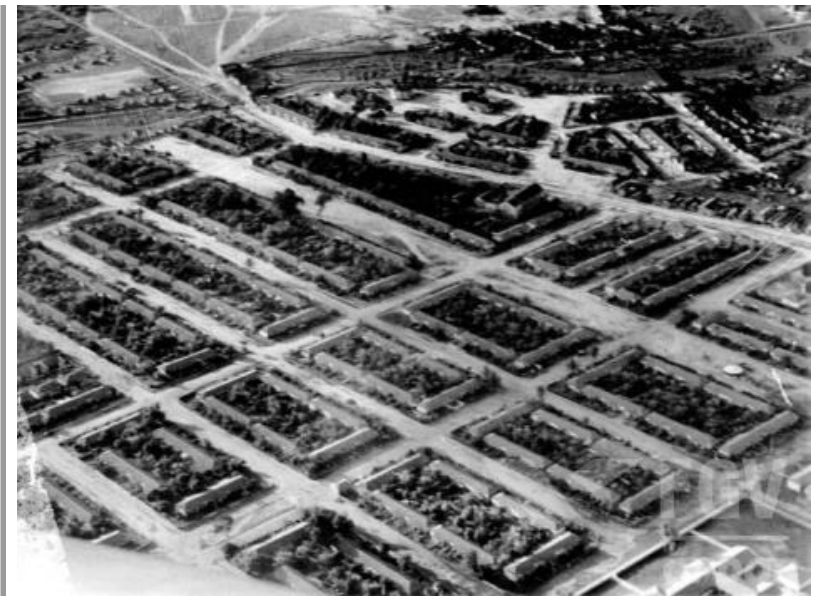

Gráfico 19: Imagem dos loteamentos da Vila da Macacheira e da Vila dos Usineiros, em Santo Amaro. (CPDOC- Fundação Getúlio Vargas)

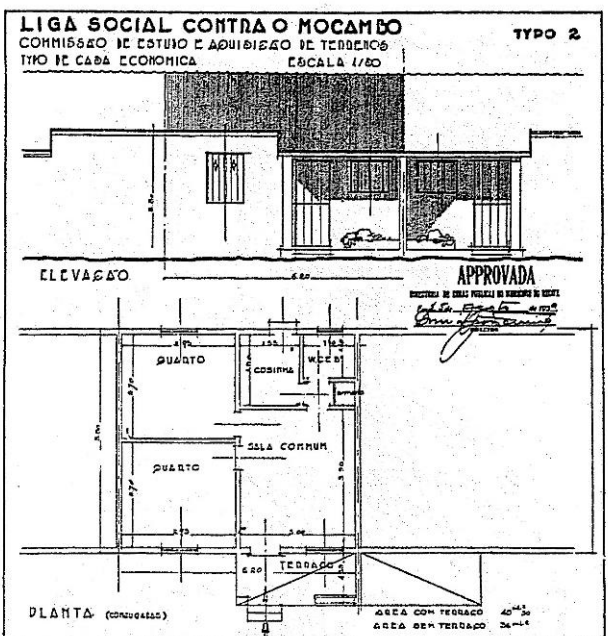

Gráfico 21: Um das tipologias elaboradas pela LSCM, para as residências, construída na Vila da Macacheira.

(Bonduki, 2014)

Com ruas prioritariamente de $12 \mathrm{~m}$ de largura e lotes com $6 \mathrm{~m}$ de frente, a maior parte das vilas populares desse bairro seguiam tais parâmetros, caracterizado ainda, pelo tipo 2 das habitações, projetadas pela LSCM, sendo a maioria construídas em séries, em grupos de seis, como observado nos gráficos 20 e 21 . É possível observar a forte presença de áreas destinadas à vegetação, porém sem locais definidos para equipamentos públicos ou demais áreas livres, verificando a política voltada para o provimento de habitação e não ligada necessariamente ao direito da moradia.

Os loteamentos populares realizados a partir da década de 1960, ora respeitavam os parâmetros definidos pelo Código de Urbanismo e Obras de 1961, ora seguia características próprias de acordo com a instituição responsável pelos mesmos. Muito desses loteamentos já apresentam tipologias habitacionais em suas plantas, enquanto outros se caracterizam apenas pelo parcelamento do solo destinado a população de baixa renda. 


\begin{tabular}{|l|l|c|c|}
\hline \multicolumn{3}{|c|}{ Diretrizes } \\
\hline \multirow{2}{*}{$\begin{array}{l}\text { Casas } \\
\text { Lotes }\end{array}$} & $100 \mathrm{~m} 2$ & \multicolumn{1}{|c|}{ Setor } & Zona \\
\cline { 2 - 4 } & $200 \mathrm{~m} 2$ & Suburbano & Residencial \\
Quadras & $40 \mathrm{~m}$ de dimensão & & \\
\hline
\end{tabular}

Gráfico 22: Diretrizes para quadras, lotes e casas populares.

Elaboração própria a partir dos dados do Código de 1961.

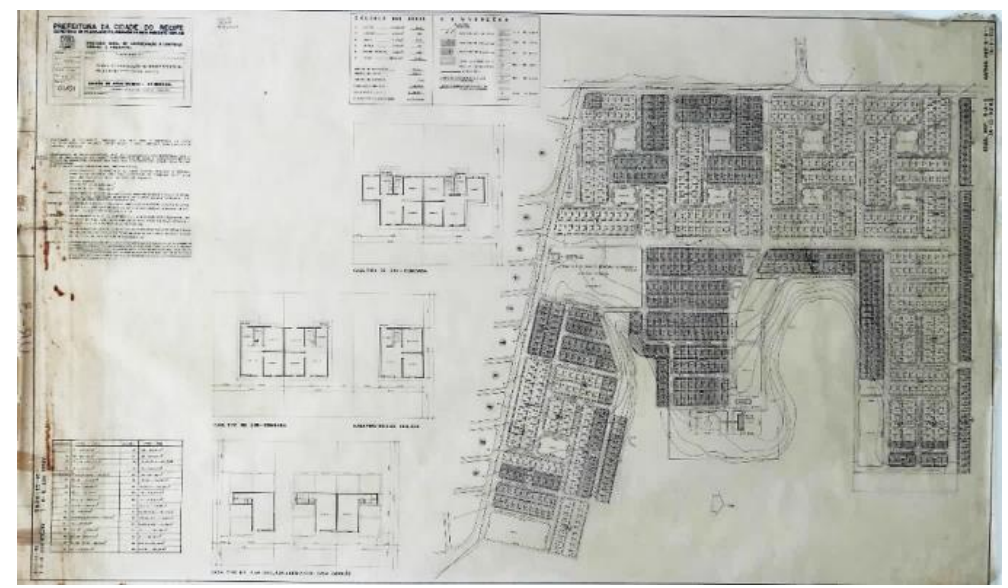

Gráfico 23: Planta de loteamento com tipologias habitacionais, localizado no bairro do lbura'.

(Empresa de Urbanização do Recife- URB)

No exemplo do loteamento da figura 23, no tocante as áreas livres e as áreas destinadas a equipamentos públicos, observamos uma pequena porcentagem dessas áreas, mesmo em grandes loteamentos (gráfico 24). Os lotes possuem, em média, $9 \mathrm{~m}$ de frente, por $16 \mathrm{~m}$ de profundidade, cujas habitações possuem, em média, $5 \mathrm{~m} \times 5 \mathrm{~m}$, sendo as maiores $8 \mathrm{~m} \times 6 \mathrm{~m}$. As áreas livres possuem em média $900 \mathrm{~m}^{2}$, enquanto a superfície de cada quadra chega a $2.300 \mathrm{~m}^{2}$. Neste loteamento podemos observar 55 quadras, frente a 14 áreas destinadas a jardins e uma praça com $1.500 \mathrm{~m}^{2}$. Uma das quadras foi doada a Secretaria de Educação e Cultura.

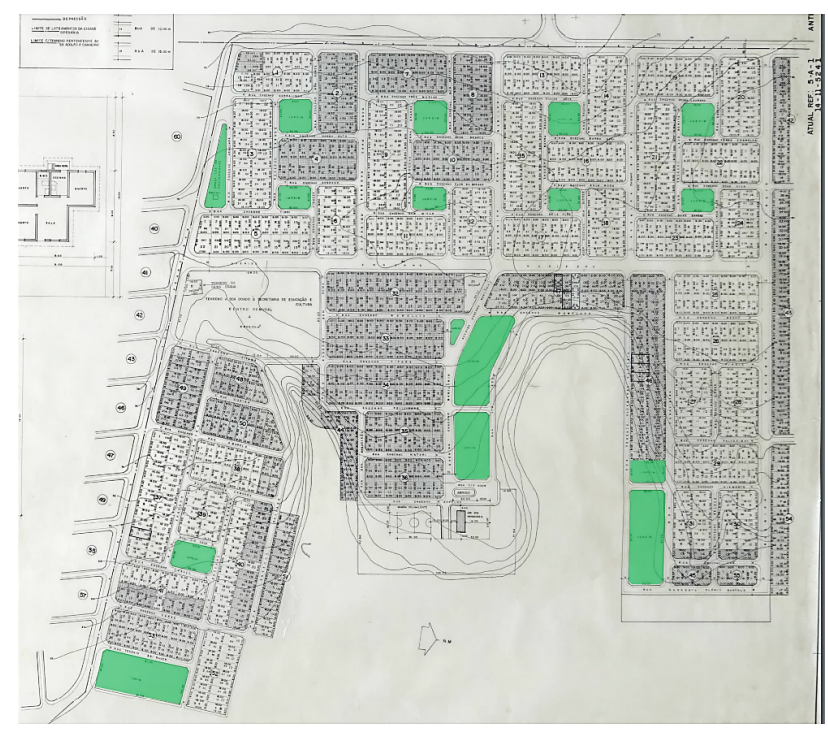

Gráfico 24: Loteamento com destaque para as áreas livres. Elaboração própria a partir de planta de loteamento.

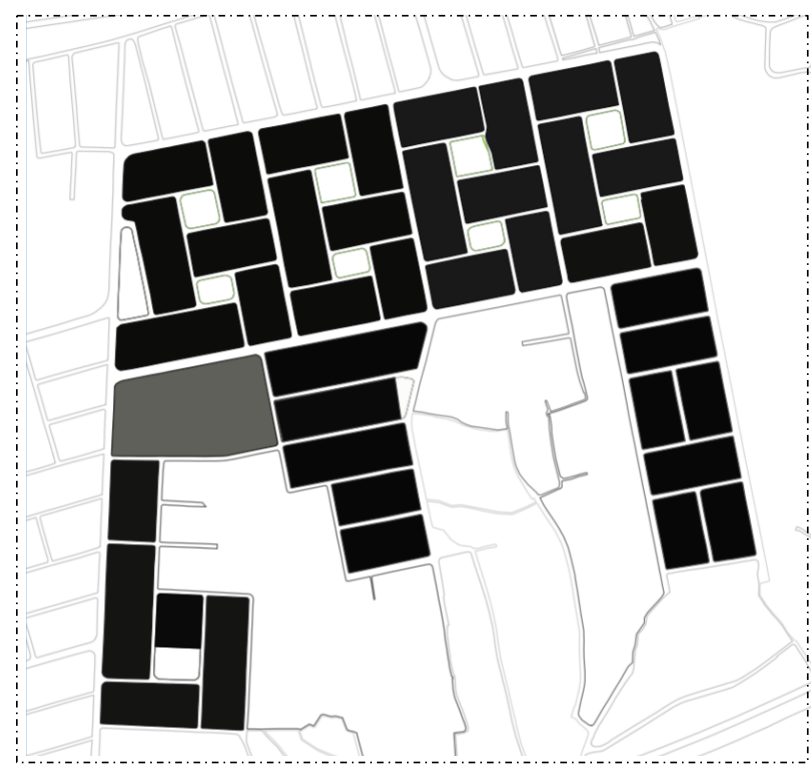

Gráfico 25: Loteamento atual, com destaque para perda de algumas áreas livres, com pouca modificação no traçado. Elaboração própria a partir de base cartográfica.

\footnotetext{
1 A área é denominada popularmente como lbura de cima, por se localizar na parte alta, próximo ao lbura. Entretanto, a Prefeitura do Recife a reconhece como COHAB.
} 
No período de aprovação do referido loteamento, década de 1970, observa-se a intensificação do processo de urbanização, especialmente quanto aos assentamentos populares. Os loteamentos e as habitações populares não supriam a quantidade populacional, continuando o processo de marginalização de grande parte da população, que adensava ainda mais as áreas de morro. De acordo com Souza (2007), enquanto os grandes conjuntos habitacionais levavam a população inserida no mercado popular para a periferia da malha urbana, as famílias mais pobres excluídas do acesso do financiado do $\mathrm{BNH}$, acabavam por somar os movimentos de invasões coletivas de terrenos. Observa-se que as casas, tanto as aprovadas no período da LSCM, quanto a partir das décadas de 1960, possuem taxa de ocupação relativamente pequena e com gabarito reduzido. São respeitadas as diretrizes de aberturas, alturas, tamanhos dos compartimentos internos e recuos.

Desta forma, pode-se verificar que a política habitacional atrelada as legislações urbanísticas e a aprovação dos loteamentos populares, não sanou, em nenhum momento, o direito à moradia da população mais carente, tão pouco forneceu habitações suficientes que abrigassem a toda população, produzindo, ao mesmo tempo, o desenho da cidade popular formal, caracterizada pelos loteamentos populares, e o desenho da cidade popular informal, caracterizado pelos assentamentos irregulares, que não derivam das legislações urbanísticas, mas da insuficiente política habitacional adotada pelo Estado. As legislações urbanísticas ora estudadas não foram capazes de traduzir as diretrizes que contribuíssem para o desenvolvimento de políticas habitacionais e um planejamento urbano adequado à cidade.

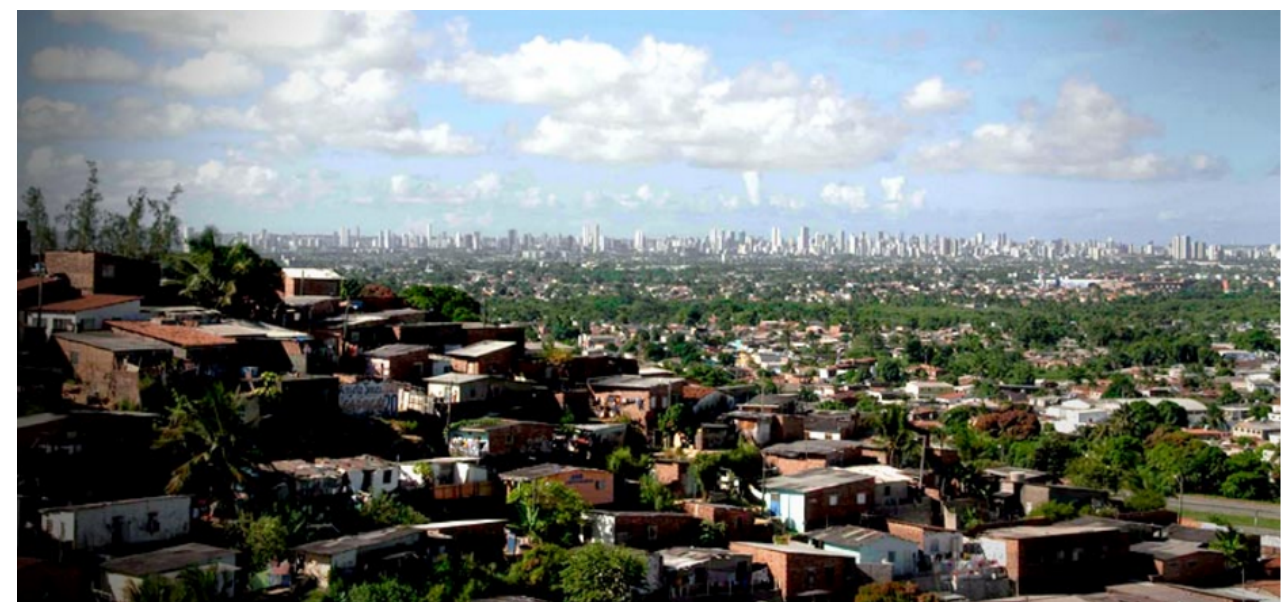

Gráfico 26: Imagem do Recife com o bairro do Ibura em primeiro plano.

(Site: http://www.michelecollins.com.br/issue/jordao/.)

No decorrer das análises e localizações dos loteamentos, verifica-se ainda, que muitos estão locados em áreas de morro, especialmente nas áreas mais periféricas da cidade, onde podemos constatar, ainda, a ausência de parâmetros que qualifiquem tais loteamentos como parte da provisão do direito à moradia. A partir do momento em que os loteamentos populares, pelo Código de Urbanismo e Obras, são destituídos da obrigação de possuir ruas calçadas, abastecimento de água, além de poucas áreas livres e áreas voltadas para equipamentos públicos, observa-se que não há, necessariamente, o direito à moradia, que perpassa o direito à habitação, não fornecendo, ainda, o direito à própria cidade.

\section{CONSIDERAÇÕES FINAIS}

Com as descobertas e análises dos loteamentos que compõem a trama urbana da cidade do Recife, podemos observar como a cidade desenhada ora inseria, de acordo com os seus interesses, a população de baixa renda, ora os excluída completamente do processo de desenvolvimento urbano da cidade. As legislações urbanísticas, que traduzem as diretrizes e desejos de uma época, que auxiliam no planejamento e no desenvolvimento urbano da cidade, acabaram por contribuir para a fragmentação do espaço, especialmente os ocupados pelas populações de baixa renda, ao zonear a cidade e permitir que as mesmas ocupassem determinados locais, em sua maioria, as margens das áreas mais valorizadas e de maior dinâmica urbana, contribuindo para uma exclusão social.

As políticas habitacionais, por sua vez, incapazes de inserir toda a população, ou a grande maioria, em seus projetos, auxiliou no desenho de uma cidade fragmentada, não suprindo o direito à moradia, não somente na provisão de mesma, como na construção de espaços públicos adequados. As diretrizes encontradas nas legislações, tanto de 1936, quanto de 1961, quando não se omitem para tal população, 
não contribuem para um desenho urbano minimamente adequado para auxiliar no provimento do direito à moradia. O estudo dessas legislações nos mostra como a cidade foi sempre pensada e planejada para população de renda média e alta, deixando a população de baixa renda sempre marginalizada, com os mínimos direitos, incentivando a locação dessa população, muitas vezes, em áreas de risco, como as encostas dos morros ou na beira dos rios. É necessário compreender como as legislações urbanísticas contribuíram para o desenho da cidade e sua fragmentação espacial e social, para que possamos adotar medidas diferentes na construção de uma cidade mais digna e igualitária.

\section{BIBLIOGRAFIA}

ALVES, Paulo Reynaldo Maia. Valores do Recife. O valor do solo na evolução da cidade. Recife: Luci Artes Gráficas Ltda., 2009.

CARVALHO, Maurício Rocha de; MOREIRA, Fernando; MENEZES, José Luiz da Mota. Um Recife Saturnino: Arquitetura, Urbanismo e Saneamento. Recife: NÉCTAR, 2010.

Guia Social do Recife. Recife, Departamento pessoal de imprensa e propaganda, 1943.

BONDUKI, Nabil. Origens da Habitação Social no Brasil: arquitetura moderna, lei do inquilinato e difusão da casa própria. São Paulo: Estação Liberdade, 2011.

LIRA, José Tavares de. Mocambo e Cidade: Regionalismo na Arquitetura e Ordenação do Espaço Habitado. Tese de doutorado em Arquitetura e Urbanismo. Faculdade de Arquitetura e Urbanismo- USP: São Paulo: 1996

OUTTES, Joel. O Recife pregado à cruz das grandes avenidas: contribuição à história do urbanismo (19271945). Dissertação de Mestrado, MDU/ UFPE, 1991.

PERNAMBUCO (1944). Relatório da Liga Social Contra o Mocambo, julho de 1939 a julho de 1944. Recife: Oficinas Gráfica de Imprensa Social, 1944.

PREFEITURA DA CIDADE DO RECIFE. Regulamento de Construções de 1936, aprovado pelo Decreto $\mathrm{n}$. 374 de 12 de agosto de 1936.

. Lei $n^{\circ} 7427$ de 19 de outubro de 1961. Regula as relações jurídicas da competência do Município do Recife, atinentes a Urbanismo e Obras.

.Lei n. 10.51, de 11 de set. 1919.

LUBAMBO, Cátia Wanderley. Bairro do Recife: entre o Corpo Santo e o Marco Zero. Recife: CEPE, 1991.

REYNALDO, Amélia. As catedrais continuam brancas. Recife: CEPE, 2017.

; ALVES, Paulo Reynaldo Maia. Origem da expansão do Recife: divisão do solo e configuração da trama urbana. A: Seminario Internacional de Investigación en Urbanismo. "V Seminario Internacional de Investigación en Urbanismo, Barcelona-Buenos Aires, junio 2013". Barcelona: DUOT, 2013, p. 877-890.

SINGER, Paul. Desenvolvimento econômico e evolução urbana: análise da evolução econômica de São Paulo, Blumenau, Porto Alegre, Belo Horizonte e Recife. São Paulo: Editora Nacional, 1977.

VALADARES, Lucia Prado. Banco Nacional de Habitação. In: Verbete, CPDOC, Fundação Getúlio Vargas.

VILLAÇA, Flávio. Espaço intra-urbano no Brasil. São Paulo: Studio Nobel, 2001. 